\title{
8 \\ The State of Mana, the Mana of the State
}

\author{
Alexander Mawyer
}

\section{Introduction}

At this point, few in our field could be surprised to hear that there is reason to be dissatisfied with an unqualified Codringtonian definition of the term mana and its extensive anthropological uptake as an 'invisible medium of power, a spiritual energy manifest in sacred objects, a potency radiated by humans' (Keesing 1984: 137; Shore 1989; Tomlinson 2006). ${ }^{1}$ Nevertheless, contemporary and historical uses of this concept in French Polynesia's Society and Gambier Islands suggest that the term continues to bear careful consideration. In the Society Islands, mana is not well attested in historical documentation reflecting everyday speech in the nineteenth century nor in midtwentieth-century ethnographers' experiences (Oliver 2002). However, today the term demonstrates extension into numerous contemporary contexts, including a significant popularisation and commercialisation. In comparison, in the Mangarevan speech community in the Gambier

1 In Codrington, mana is famously 'what works to effect everything which is beyond the ordinary power of men, outside the common processes of nature; it is present in the atmosphere of life, attaches itself to persons and to things, and is manifested by results which can only be ascribed to its operation' (Codrington 1891: 118). 
Islands, mana is also remarkably absent in the limited record of nineteenth-century texts, and is today not much more visible in contemporary use and then only within a narrow range of expression. In this regional contrast-increasing usage of mana in speech on Tahiti in comparison with an enduringly limited everyday usage on Mangareva, processes I describe as a 'quotidianisation of mana' on Tahiti and a culture of 'anti-quotidianisation' on Mangareva - I examine a moment in which mana came into visibility for one Mangarevan man grappling with issues of personhood, legal status and state authority. I argue that this instance reveals something about the tension between the disciplinary uptake of Robert Henry Codrington's formulation of mana as indicative of 'supernatural' powers which are 'outside the common processes of nature' and 'beyond the ordinary power of men' (Codrington 1891: 118) as opposed to vernacular conceptions of remarkable worldly power. At the same time, this pragmatic inflection of contemporary mana sheds interesting light on its sometimes changing trajectories of regional use.

\section{Bare mana}

With astonishing regularity, mana's lightning-like and thunderous bursts onto the anthropological scene have seen it deployed along Codringtonian lines or in conversation with them. Marshall Sahlins' (1985) work on the life and death of James Cook might be seen to capture the century-long drift of the disciplinary commonsense in which mana appears to have a substantial, supernatural and mobile quality that imbues persons and things with heightened salience or potency. Sahlins suggests that the spiritual, indeed ineffable, character of the experience of persons and their external relations to objects and others is calibrated by the concept of and term for godhood or divinity, in Hawaiian akua, from whom all mana flows. Thus, at first glance, the special status accorded to the stranger-king/British naval officer seems to be a question of his divinity and not of his quotient of worldly power. Sahlins writes with typical piquancy, 'Nothing human was truly foreign to the Hawaiians - if not always the other way around' (Sahlins 1985: 30). However, if Cook was the akua Lono among men, Sahlins' account actually shows it to be his mana that they were after. Thus, 'the mana of the sacrificed Cook devolved on the Hawaiian chiefs as a sign of their legitimacy' (Sahlins 1985: 74). 
That is, in Islands of History mana plays the key role in the analysis, in a story which after all seeks to account for an economy of spectral force, not an economy of godliness. ${ }^{2}$

A later passage beautifully captures the way this term is framed as significant to the category of human beings, setting out types of persons, social roles and implications for action. 'On the other hand, Cook's hubris was as much Polynesian as it was European ... He would have died, then, a truly Polynesian death: the death reserved for the man who has accumulated so much mana, he is tempted to defy the rules that govern ordinary men' (Sahlins 1985: 134). Mana serves then as the anthropological measure for evaluation between kinds of beings or entities. Mana invokes a metaphysical market, or exchange, in which words, things and the persons who possess them calculate their value through the machinations of a literally invisible hand. It is the gold standard against which everything stands comparable, a 'native theory' that stands 'Marx on his head by its insistence that ("in the final analysis") the economic base depended on the spiritual superstructure' (Sahlins 1985: 8). Mana is heady anthropological stuff - on one hand strong evidence of the necessity of culture for describing and explaining the perception, conception and experience of human affairs in specific social contexts, and on the other hand a readily deployable model for universalised arguments about the intersection of religion, psychology and politics in the ordering of the social. Even as weighty interpretive purchase on mana was sought and re-sought over the last century more or less along Sahlinsesque lines, it is curious to note that it was also perceived, for at least half that time, as something of a conceptual nullity, a hollowed out semantic vessel to be filled by the interpretive bias of the anthropological

2 According to Valerio Valeri,

It is clear that in the Maori notion of mana as reconstructed by Johansen the idea of efficacy is prominent, particularly as it applies to social relations. But contrary to what happens in Melanesia according to Keesing, this efficacy is grounded in a philosophy of life based on the idea of growth - that is to say, a concept much more encompassing than 'luck'. Moreover, the hierarchical and relational dimensions of mana are emphasised: although from the point of view of an individual mana is life turning outward, influencing less vital beings, it is also and more importantly a relation linking all of them and therefore not located in that individual only. Mana is, in a sense, the efficacy of a system of relations personified by an individual (for instance a chief): it is the notion that the system 'works'. This notion of mana perhaps confirms Hubert and Mauss' intuition that mana identifies more with the 'circle' connecting the terms said to be mana than with the terms as such (Valeri 1985: 97). 
commentator (Lévi-Strauss 1987). Cloaked as it is in the ambiguity rising from too much or too little semantic content being reserved for it (Holbraad 2009; compare Kolshus, this volume), there is a real risk of throwing out the concept with the bathwater of critique (Shore 1989; Tomlinson 2006).

\section{Table 5. Attestations of mana in Mangarevan.}

Mana 1. Powerful, mighty; 2. Miraculous, marvelous, supernatural; 3. Existence, being; 4. Provocation; 5. Divination; 6 . A quoit used in a game resembling hop-scotch; 7. To hold a higher card of the same suit.

'Akamana [+caus] 8. To make powerful; to give authority to a person. Managa [+nom1] 9. A mighty action, something marvelous and extraordinary.

Manaraga [+nom2] 10. Power, might; 2. Omnipotence.

Manamana [+redup] 11. To send to fetch anything without the consent or authority of its owner; 12. The conqueror in a race, competition, or trial of skill; 13. The object of divination, of research.

'Akamanamana [+caus, +redup] 14. To divine; to foretell. To propose to foretell.

Mamana [+ partial redup] 15. To prevent one being employed on certain duties; to prohibit. 16. To respect oneself; to respect each other.

Manamanaua [+redup, +mod] 17. Many, said of 40 persons and more.

Source: Compiled from Tregear 1899 and [Janeau] 1908.

In French Polynesia's speech communities mana is alive and well. Traditional syntactic and semantic regularities of use resonate with long enduring regional and super-regional cultures of mana (Blevins 2008; Blust 2007; compare Rumsey, this volume) and also point to entirely contemporary cultural formations. Although questions remain about the relationship between the general and the specific, between putative definition and cultural use, and between the overor under-determined theoretical model and specific local conceptions and experiences, anthropological purchase on the term seems possible. For instance, examination of the lexicographical traditions stemming from the work of nineteenth- and early twentieth-century Catholic missionaries on Mangareva - the primary island of one of the five archipelagos that comprise French Polynesia-offers partial evidence for the enduring character of mana in part of Oceania (see Table 5).

With respect to significant previous work on mana's lexicographical tradition and the various controversies over its status (Keesing 1984; Shore 1989), I want to draw attention to several features of these records. Comparable to lexical work elsewhere, such traces of nineteenth- 
century Mangarevan certainly suggest mana as ontologically lush and semantically verdant. At the same time, syntactical elaborations of mana do not point to quite the same breadth or verdant lushness. In Mangarevan, the causative, nominalised and reduplicative forms indicate a narrower primary semantic field of pragmatic authority and practical powers. Moreover and despite the clarity of the dictionary entries, surviving nineteenth-century Mangarevan texts, the manuscripts and commentaries on traditional histories called atoga (Pacific Manuscript Mangareva; see Buck 1938 for a partial history of their provenance), have few uses of this term applied to a narrow range of entities even though the extraordinary characters, actions, and things of pre-Christian gods, heroes and chiefs are all but their only subject (see Table 6).

Table 6. Use instances of mana in Mangarevan atonga (traditional histories).

\begin{tabular}{|c|c|c|}
\hline Instance & Gloss & Application \\
\hline $\begin{array}{l}\text { 18. O te vaka o Niu, tau ki 'Avaiki, } \\
\text { aruara ta Turiakainoa ki à toa, e mea } \\
\text { mana, (MPM 3.3:61) }\end{array}$ & $\begin{array}{l}\text { Of the canoe of Niu ... a thing } \\
\text { of mana, }\end{array}$ & Canoe \\
\hline $\begin{array}{l}\text { 19. Ko mana i Tautoro ara noti, } \\
\text { 'à marae tana i 'akatu i 'Akamaru, } \\
\text { (MPM 3.3:66) }\end{array}$ & ... mana at [of] Tautoro himself, & Man \\
\hline $\begin{array}{l}\text { 20. O te vaka o Niu, tau ki 'Avaiki, } \\
\text { aruaru ta Turiakainoa ki à toa, e mea } \\
\text { mana, (MPM 3.3:83) }\end{array}$ & $\begin{array}{l}\text { Of the canoe of Niu ... a thing } \\
\text { of mana, }\end{array}$ & Canoe \\
\hline $\begin{array}{l}21 . \text { I reira, kua tagi ko Turi-a-kainoa ei } \\
\text { toa mana ko Ina-Raurega te toa i te } \\
\text { vehine ona (MPM 3.4:27) }\end{array}$ & $\begin{array}{l}\text { Then, Turi-a-kainoa wanted a } \\
\text { woman of mana ... }\end{array}$ & Woman \\
\hline $\begin{array}{l}\text { 22. Ena i te toa mana ko Aumea } \\
\text { (MPM 3.4:28) }\end{array}$ & There is a mana-woman Aumea & Woman \\
\hline $\begin{array}{l}\text { 23. Putuputu ke te karokaro me } \\
\text { te patuga, e ko roa e akoako no } \\
\text { manamana hua. (MPM 3.4:51) }\end{array}$ & $\begin{array}{l}\text {... the manamana'ua (assembled } \\
\text { mass) [of combatants] practiced } \\
\text { crying out. }\end{array}$ & Collective \\
\hline $\begin{array}{l}\text { 24. Ko Pakoiti nei hoki e toa tagata } \\
\text { noti, kakore tona mana. (MPM } 3.4: 65 \text { ) }\end{array}$ & $\begin{array}{l}\text { Of Pakoiti truly a woman, } \\
\text { her mana negated. }\end{array}$ & Woman \\
\hline $\begin{array}{l}\text { 25. Ku takaohia kia Teriki mana e } \\
\text { tinai. (MPM } 3.4: 83 \text { ) }\end{array}$ & ... Teriki mana in the striking. & Man \\
\hline $\begin{array}{l}\text { 26. Ki atu ko Te Magi ki tona teina } \\
\text { ko Korotauiti, 'Aia to etua ka igogo, } \\
\text { me hakatere vaka o taua. Ite koe te } \\
\text { mana.' (MPM } 3.4: 88 \text { ) }\end{array}$ & $\begin{array}{l}\text {... 'You stretched out to the } \\
\text { mana.' }\end{array}$ & Man \\
\hline
\end{tabular}




\begin{tabular}{|l|l|l|}
\hline Instance & Gloss & Application \\
\hline $\begin{array}{l}\text { 27. Ovatu ki te teina ta Te Akariki-tea, } \\
\text { mana e hakauta. (MPM 3.4:98) }\end{array}$ & $\begin{array}{l}\text {.. mana [of] causing to go } \\
\text { upland. }\end{array}$ & Action \\
\hline $\begin{array}{l}\text { 28. Paru ta Toa-pere ki ana, aruaru. } \\
\text { Kakore ra koia ei hao ki te tagata ke } \\
\text { a noti e toa tuhuga hakamamana. } \\
\text { (MPM 3.4:119) }\end{array}$ & $\begin{array}{l}\text { [prevented, ie dis-authorized] it. } \\
\text { [pre-woman 'akamamana }\end{array}$ & Action \\
\hline $\begin{array}{l}\text { 29. E kore te etua e tiki ki te haga } \\
\text { mana me turu ki te hu Aieretiko.' } \\
\text { (MPM 3.4:124) }\end{array}$ & $\begin{array}{l}\text {.. The tiki of the gods are not } \\
\text { works of mana that supported } \\
\text { the Heretical people [of pre- } \\
\text { Christian times]. }\end{array}$ & $\begin{array}{l}\text { Tiki (carved } \\
\text { figure) }\end{array}$ \\
\hline
\end{tabular}

Given this tradition of use, recorded in both the atoga and lexicographical contexts, a bare bones sense of mana's invocation and application in nineteenth-century speech in this community looks something like Table 7.

Table 7. Summary of mana's ascriptions from Tables 5 and 6.

\begin{tabular}{|l|l|}
\hline Ascription & Domain \\
\hline Game-of-chance pieces, canoe, tiki 6, 7, 18, 20,29 & Objects \\
\hline Women and Men 12, 19, 21, 22, 24, 25, 26 & Persons \\
\hline Groups 17, 23 & Collectives \\
\hline Empower, authorise, task, prohibit 8, 11, 14, 15, 27, 28 & Actions \\
\hline
\end{tabular}

In the scant surviving textual evidence of Mangarevan traditions of use there is thus a remarkable tension between the seeming possibility of semantic extension, applicability, appropriateness and felicity in the lexicographical tradition for possible use of the term and evidence of actual application. In recorded discourse, mana appears in secular qualities of practical powers and regimes of authority, in material properties of objects, and in natural notions of force that are not 'outside the common processes of nature' or 'beyond the ordinary power of men' (pace Codrington), but manifest in the crispness of everyday life and the concrete social powers of human beings working in unison. There is no strong evidence that mana was regularly expressed in this speech community, nor does it appear to have been particularly ambiguous in its application to certain kinds of objects (things, persons, actions). Its attested use in the nineteenth century appears to have been limited, circumspect and rare. 
How does this pattern of limited use compare elsewhere within this part of Polynesia? Douglas Oliver for instance notes:

in fact, mana occurs quite infrequently in utterances attributable to 18th and early 19th century Tahitians. One example of such was characterization of a village council as being e pupu mana, a group having legitimate authority and positive coercive power. Another was reference to a canoe as having been well-laced and ornamented with sacred coconut-fiber cordage, and thereby possessed of mana, i.e., sturdiness, stability, and speed of passage. (Oliver 2002: 23)

By way of further comparison, Valerio Valeri observes a similar absence in early surviving Hawaiian texts, especially the luakini temple rituals which were 'the most important occasion for the transmission of mana from the divine to the human realm' (Valeri 1985: 97). Notably, Valeri argues that perhaps we should not be surprised that the object of the ritual itself (mana) goes, relatively, unnamed; 'to think otherwise would be to confuse the texts with the complete accounts of what happens in ritual and especially of what is presupposed throughout it and therefore does not have to be explicitly stated' (1985: 98). ${ }^{3}$

In Tahiti, Oliver's examples of mana attributed to political collectives and individuals or things of dependable, effective and practical powers are still normative and common. Thus, as Jean-François Baré records in contemporary Tahiti, there is Ia Mana te Nuna'a (Power to the People), a political party, and Feia Mana (People of Mana), both of which seem to indicate something about the secular potency of civil society. Indeed, Barés account of mana strongly points to a pragmatic and nominal understanding of the term, although he claims, citing Max Weber's notion of the disenchantment of modernity, that the authentic magical-political function and understanding of the word was corrupted by contact with the West. Furthermore, he claims this depletion theory corresponds to an important modernist current of local experience in the region (Tomlinson 2006). Thus, he gives as an example the Ma'ohi (Tahitian) politician Pouvana o O'opa's comments in a postwar speech to the French Polynesian leaders assembled to consider a postcolonial future that 'notre mana n'etait pas tres fort (puai) a ce moment-la' ('Our mana was not very strong at that time')

3 This argument would perhaps seem less forceful coming from anyone else. 
and 'quand on a du/un mana sur ( $i$ ni'a) une terre, c'est en fait des droits sur cette terre' ('when one has mana over a land, that is in fact rights over this land') (Baré 1987: 480).

In addition to such weighty usage enduring from the past and greatly resembling attested uses in the closely related but distinct Mangarevan context, perhaps the most remarkable thing about Tahitian mana emerges in its contrastive appearance in contemporary use. Today on Tahiti mana is increasingly deployed in popular cultural contexts. Mana-saturated shopping, mana-enhanced t-shirts, mana-infused internet or wifi access, popular musical groups, mana-effervescing beverages, mana-enhancing pearls, tattoo parlours (and presumably their tattoos), imported industrial-mana machinery, and manamediating dance have all emerged in recent years.

Available from dedicated boutiques on the island of Tahiti, as well as from numerous other venues, pareu and shirts designed and dyed in Tahiti have been offering wearable mana for years (Figure 14). According to their Facebook page, Te Mana

signifies the universal force present in everything and every being. It is also the name of a celebrated brand of Tahitian shirts. The label Te Mana is everywhere celebrated for its shirts for persons of great qualities, available in a multitude of styles and colors ... Te Mana also sells clothing for women and children also designed with Pacific motifs, and fabricated with the attention to detail and quality.

The conspicuous consumption of mana is not limited to terrestrial fabrics. Several pearl producers and boutiques index mana in their firm name and attach the term to their wearable products (Figure 15). Indeed, you too can be a Mana-Boy (or Mana-Girl), by acquiring a 'pearl of mana' and 'discovering the secrets of the "Le Chemin de la Perle (C)" (the path of pearl)' (Manapearl 2015). 
8. THE STATE OF MANA, THE MANA OF THE STATE

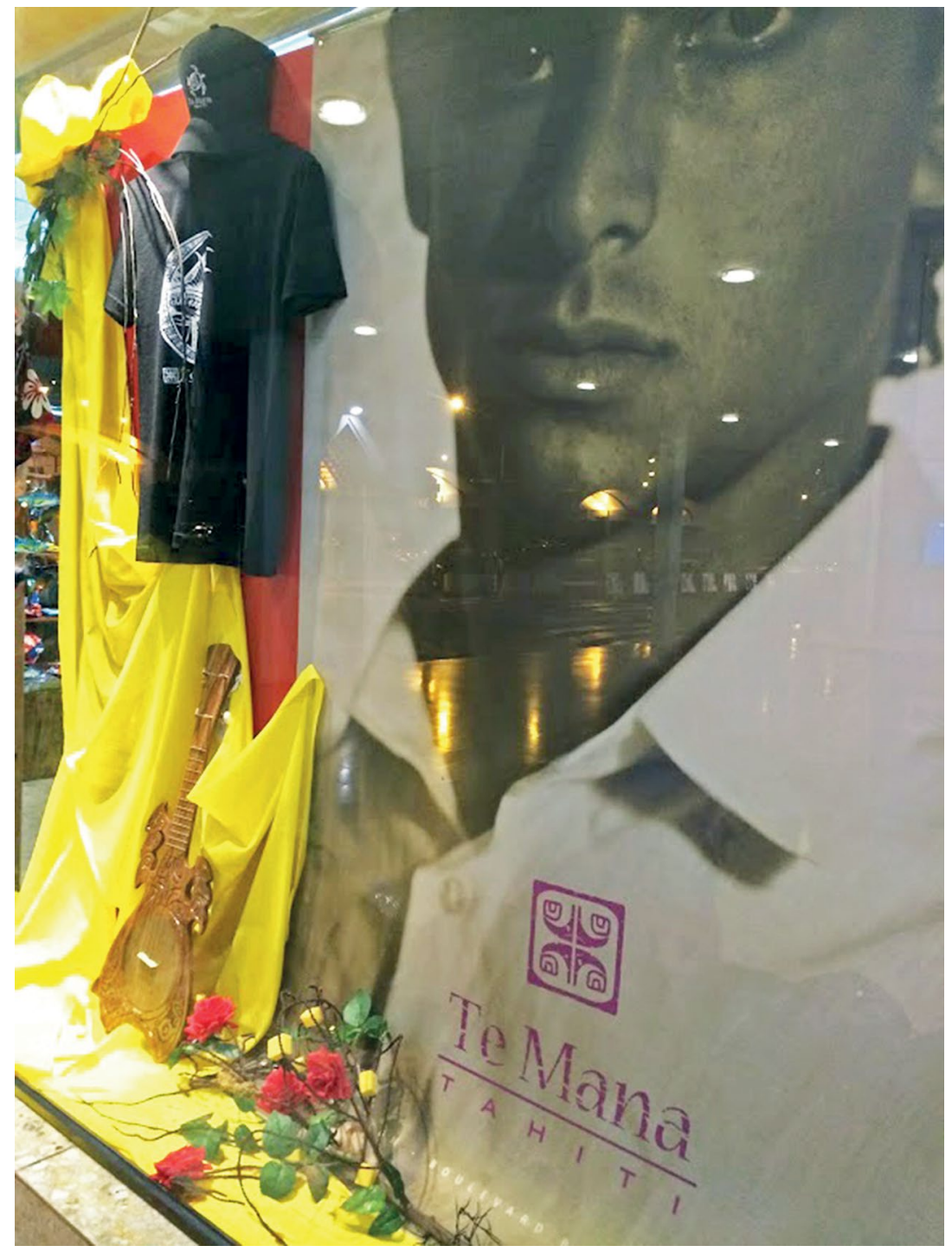

Figure 14. Te Mana clothing brand.

Source: Photograph by Alexander Mawyer, June 2014. 


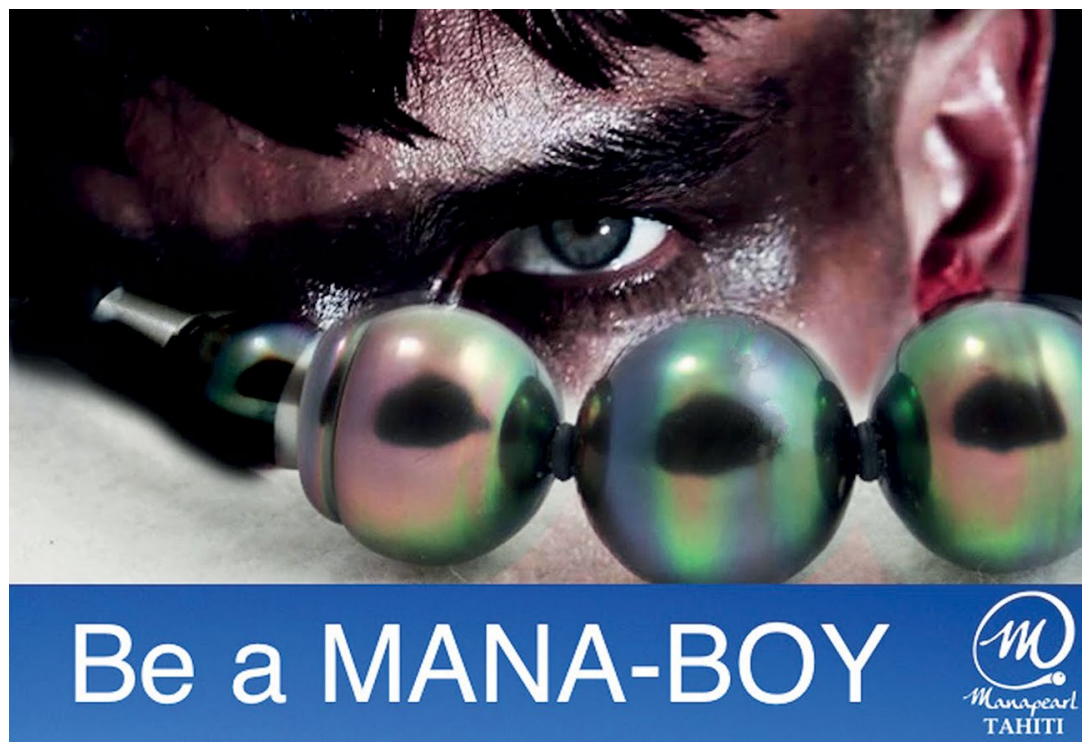

Figure 15. 'Be a Mana-Boy'.

Source: Manapearl Tahiti 2014, used with permission.

The proposed absorption or transfer of mana is not limited to acquired possessions. Experiences too, are being attached to the mana 'brand'. Mana Rock Café (Figure 16), long noted in regional guidebooks for evening entertainment in Papeete, is contextualised by other manarocking venues and experiences, including massages, hostelries and tattoo parlours.

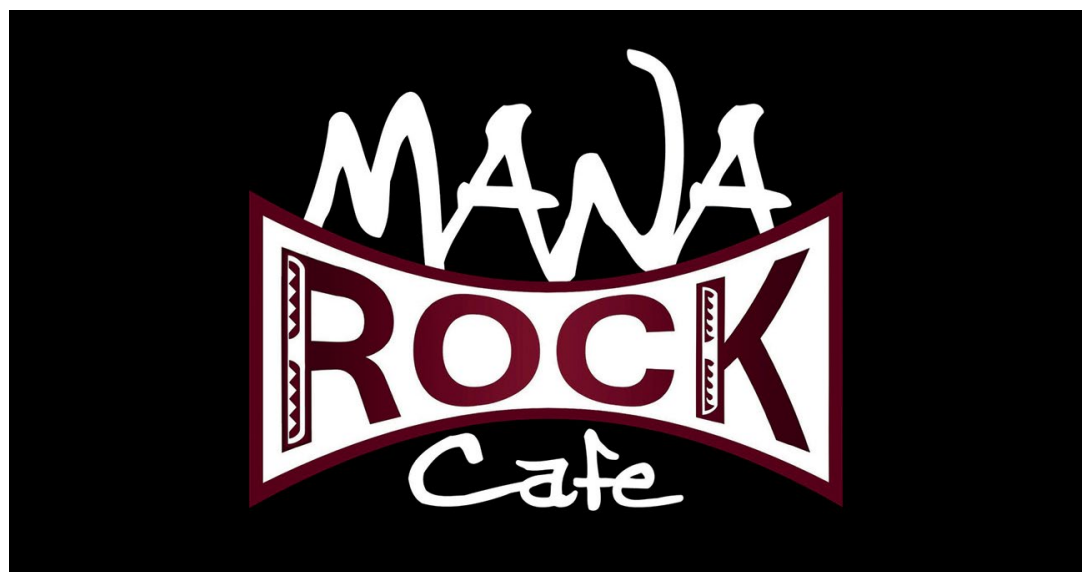

Figure 16. Drinking mana.

Source: Mana Rock Café website 2014. 
Perhaps the most quotidian encounter with mana in contemporary French Polynesia is mediated by the VINI Corporation's internet arm with its several mana-infused (and infusing?) subsidiaries including Mana L'Internet Polynésienne (Figure 17) and its separate business ManaSpot offering 'The Polynesian Wi-Fi connection, in all liberty, it's ManaSpot!' Other offerings include the rental of a Manabox ${ }^{\mathrm{TM}}$ router and the Manamail service, 'Rediscover the pleasure of communicating!'

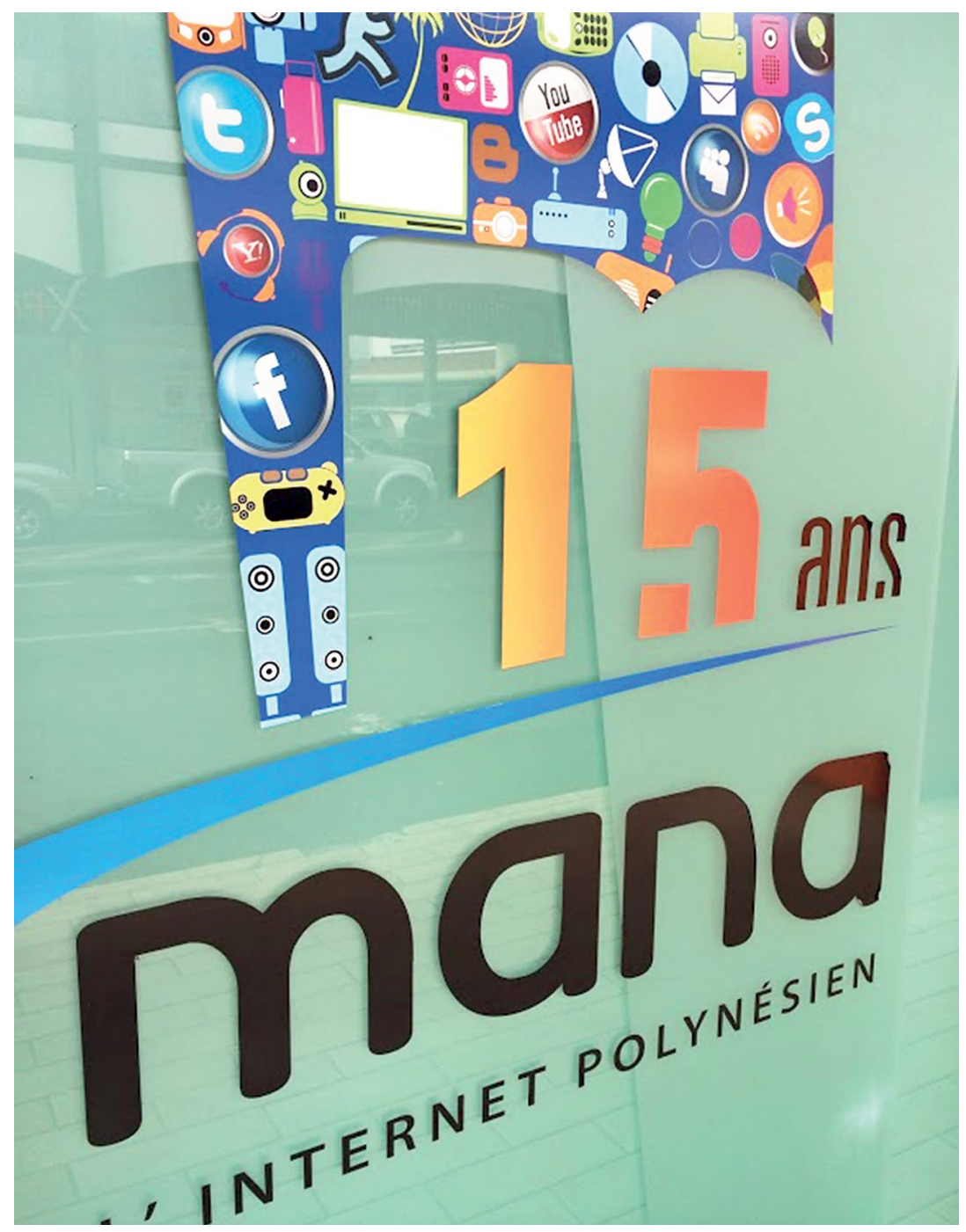

Figure 17. Mana-infused communications.

Source: Photograph by Alexander Mawyer, June 2014. 
Mana is not only found in the things and experiences one can now, with daily regularity, consume; it also supports the very sites of consumption. Still under construction in 2014, the Mana Nui Shopping Mall (Figure 18), also known as the Takau Plaza Shopping Center in Papeete, is not the only commercial shopping centre to take this name. The major French grocery chain Carrefour's (crossroads) building in Fa'a is also the Mana Nui Building.

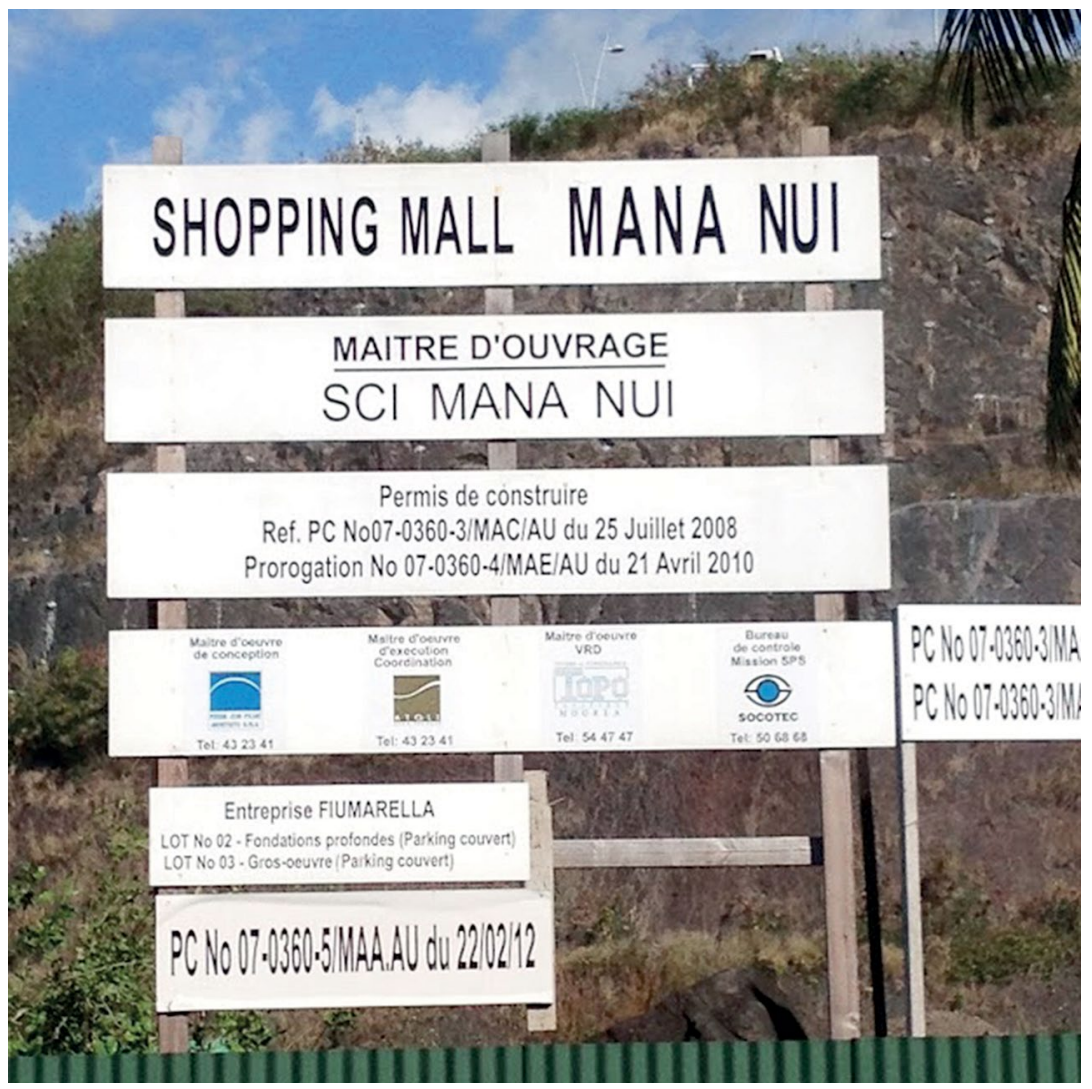

Figure 18. Mana shopping.

Source: Photograph by Alexander Mawyer, June 2014.

Profoundly historically and socially charged collective associations such as the political party Ia Mana te Nunaa (Power to the People) formed in 1975 by Henri Hiro and other leaders in the Tahitian cultural and political renewal of that era, are not the only popular associations to assert the mana of collectivity. For instance, Mana o te Reo (Mana of the Language) works commercially to provide Tahitian 
translations for various public and private entities, the Mana o te Moana (Mana of the Ocean) foundation supports marine conservation and public education in the region, and a popular mana-enhanced and enhancing Tahitian dance association has been active in France and Tahiti since 2006 (Figure 19).

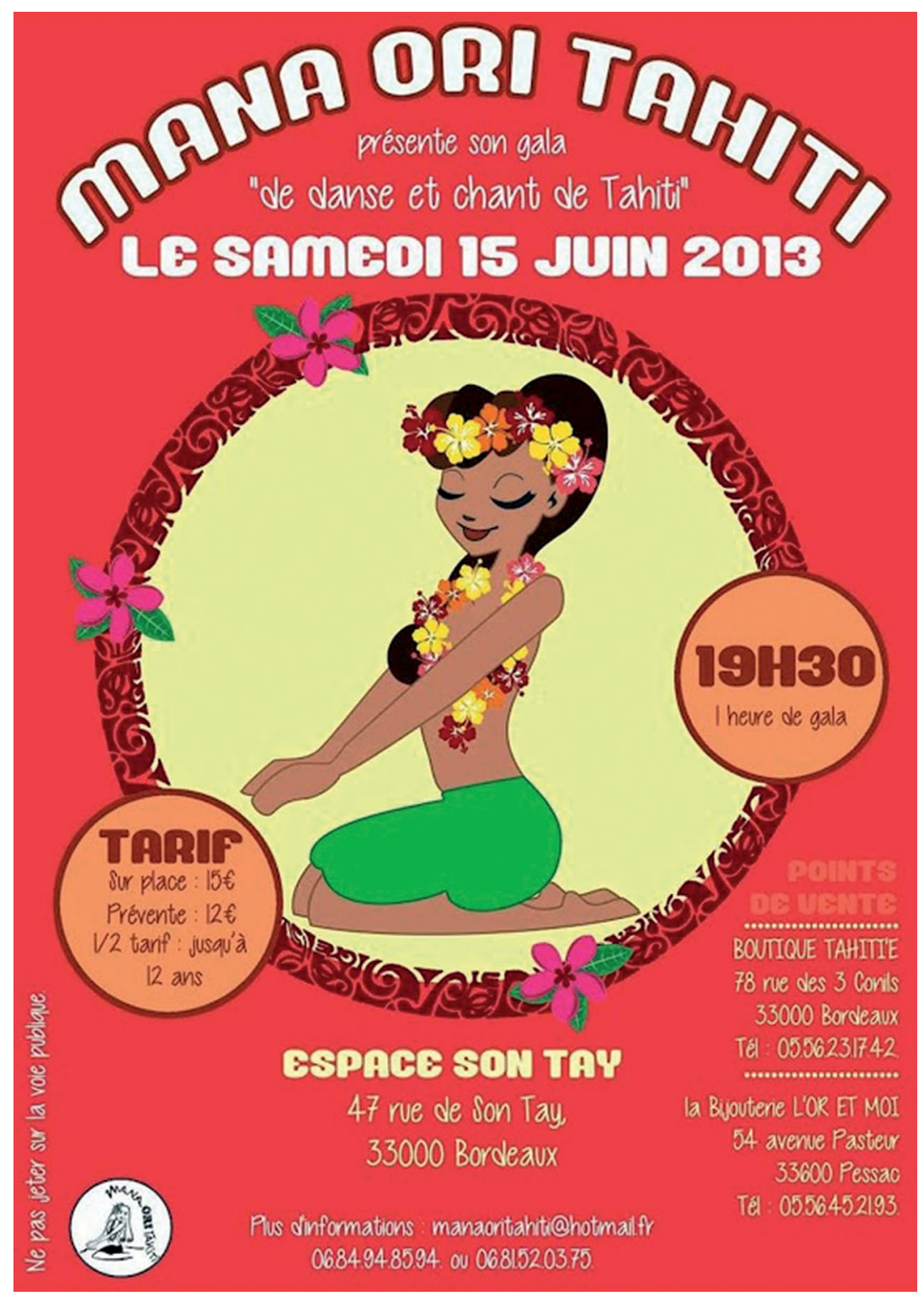

Figure 19. Choreographing mana (Mana Ori Tahiti 2015). 
Do advertisements seeking to enhance claims about the potency of products demonstrate that, on Tahiti, mana is being corrupted by the West, hollowed out even as it expands in its reach? Do they suggest that a western corruption - the disease of someone else's culture - has tainted mana at its source or in its expressive realisation? Contra Baré, I note that modernity and its playing-out is not everywhere identical (Appadurai 1996). While it may be entirely accurate that the march of modernity in the West included this process of disenchantment, it may also be true that western disenchantment was in part made possible by various displacements and transferences which resulted in a heightening of the senses of the potent and the occult elsewherewhich is to say that I am not at all convinced that whatever mana has been in Tahitian contexts it has now been stripped and etiolated of past potency. Rather, the fact that mana, whatever it signifies, is in evergreater extension in everyday contexts may well point to a process of quotidianisation but not necessarily of etiolation and depletion. The argument that the semantic extension to cover a broader range of situations, goods and aspects of personhood than in the past must mean that the term is increasingly emptied out-as opposed to the possibility that this range of situations, goods and everyday contexts have taken on meaningful cultural inflections - is a judgment with which I am not comfortable. That is, from the point of view of lived experience, and in contrast to Barés interpretive stance, some aspects of contemporary life in the French Polynesian regional center of Tahiti now seem more enchanted, not less.

But what might quotidianisation suggest about the underlying culture of mana, and is this pattern of quotidianisation playing out in the same way across the region? To answer such questions with sensitivity to the emplacedness of culture, fieldworkers and critical commentators alike are better served by attending to the term's everyday economies of usage in specific social and historical contexts. On Mangareva, as shown in the next section, an account of mana in enduring and contemporary culture suggests a markedly different trajectory of usage than in Tahiti- one in which the term's semantic extension is scarcely broader than in the past but is, as yet, resisting quotidianisation.

Indeed, on Mangareva, over the course of multiple visits between 1999 and 2009, and particularly during my doctoral fieldwork in 2002 and early 2003, I only witnessed the term 'mana' used on a small number of occasions. These included several references to the aga mana 
(mana-works) of ancient culture heroes and chiefly persons, and on a number of occasions to e mea mana (mana-things or doings) when referring to objects and public works whose purpose and meanings are either lost to record or memory, obscure, or understood with difficulty relative to the amount of labour involved in their construction. Such mana-works include the cathedral and certain other works of the early mission period. Massive works that predate the construction of the cathedral were also often couched in terms of 'aga mana: the rolling of a massive coral boulder to the top of the ridge where a paved road now crosses over the ridge line, the raising of several massive platforms (termed paepae) in the mountains, the now lost marae, and the handhewn and polished stone benches and massive stone anchors used for the ritual sea-burial of certain prestige-filled remains (not those of high chiefs, however, who had a specific burial site on land). Several senior speakers with whom I worked on a dictionary project initiated by the Association Culturelle Reo Mangareva (Mangarevan Language Cultural Association) also spoke with me about naue (divination) and the tapa'o (signs) of natural events, doing so with reference to the persons capable of such acts as tagata mana, people of mana. ${ }^{4}$ These instances could be tallied on my two hands. When speaking with a Mangarevan colleague about this pattern of scarce use, he observed, 'This is not surprising, mana is a tapu word', ${ }^{5}$ one set aside, one that should only be invoked when appropriate.

Although all of these instances of use might indicate something like the sense of mana's second definition above (miraculous, marvelous, supernatural) and are notably identical to the scant uses recorded in the Mangarevan atonga, I suggest something else lingers in the semantics besides the supernatural and extraordinary-something more in line with the sense of practical powers and authorities. In my fieldwork, there was a singular context of use that puzzled me and that suggested the practical and worldly place of mana on the landscape of contemporary (and perhaps past) Mangarevan discourse.

4 The attachment of mana to the parapsychological evidenced in these usages is locally worrisome, however, in its potential motivation by the slender and regionally much read and referred to book Mana by an itinerant French aristocrat and new-ager who interpreted the concept along western occult lines (Putigny 1993). Robert Putigny is, coincidentally, the father of one of my Mangarevan informants who taught me something rather profound about local conceptions of 'silence' - quite a small world as it turns out.

5 Ena Manuireva, personal communication, Skype, Spring 2014. 


\section{Herangi means Pitcairn}

Having written on the Bounty and its various instantiations in film several times since entering graduate school, I was conscious of how close Pitcairn (called 'Erangi' in Mangarevan) was to the Gambier Islands of French Polynesia. Prior to the construction in the 1960s of an airstrip on one of Mangareva's motu sand islets dotting the 100-kilometre reef, both islands shared their commercial and transportation regimes to a great degree. Ships hailing at one island hailed at the other and a vigorous trade of goods, resources, and news was maintained. I was delighted early in my fieldwork to 'discover' that the historical relationship between these two islands survived into the twentieth century. However, the cold-war advent of French nuclear testing had changed much, and an invisible wall seems to have been thrown up between the islands, greatly complicating what had been enduring inter-island kin groups, exchange networks and, more interestingly, inter-island property rights. I heard reports of disincentives for Mangarevans to travel to Pitcairn or other nearby islands (Henderson, Ducie, Oeno) where many persons claimed traditional rights of access and use earlier in the century-including explicit prohibitions on travel imposed by the gendarmes.

Despite such obstacles as changes in the material infrastructure of island lives and the ethereal superstructure of state politics (n.b. Pitcairn, a British Colony to this day, is administered by New Zealand, generally governed by a High Commissioner operating out of New Zealand - a state that staunchly opposed French nuclear testing, proposed the South Pacific as a Nuclear Free Zone, and was the outraged host of the Greenpeace flagship Rainbow Warrior scuttled by French special forces in Auckland Harbour in 1985), I discovered not long after my arrival that some individuals on Mangareva are commonly understood to be 'Pitcairners' despite, in some cases, having been raised on Mangareva and also being of Mangarevan descent, in addition to the Tahitian and Tubuaian toto (blood) that all Pitcairners have through the maternal line. Later, when by pure coincidence a senior member of the Christian family, ${ }^{6}$ Charles, arrived on Mangareva en route with his

6 From what I gathered first-hand on Pitcairn during a brief visit in 2002 and from Charles Christian on Mangareva, the social organisation of Pitcairners on Pitcairn, Norkfolk Island, New Zealand and elsewhere is felt to be closely aligned to certain Polynesian precedents including a sense of ranked superiority by birth order and 'family' (clan) arrival order, e.g. the Christians take precedence over Adams and others, who all in turn take precedence over the several families of American-descended jump-ships. 
wife to visit Pitcairn and was kind enough to invite me to dinner and to taste her 'famous' Pitcairn pie (a freshly grated coconut crème/dried banana masterwork), I learned that other folks on Mangareva, not merely those who were socially marked as 'Pitcairners', maintained family and economic ties of various sorts with Pitcairn mediated by the occasional yacht passing in the countervailing direction. In some cases such ties, I learned, extended back three or four generations and were rooted in the commercial relations of merchants, copra traders and ships' pilots. Many Mangarevan adults are deeply sensitive to what Pitcairners are likely to be wanting at any season of the year, especially with respect to the potentially many-months cargo cycle of that island. In comparison, Mangareva is served by weekly flights and two cargo ships that circle through French Polynesia on alternating three-week cycles. Thus cargo arrives optimally every two weeks, but sometimes twice in two days, and sometimes not for six weeks or more if there is a delay, resulting in palate-numbing culinary boredom, hoarding and quite a rush on the day when the bakery is understood to be putting its last loaves in the oven until the cargo's next arrival.

After long months in the field wishing for a suitable yacht to offer serendipitous passage, I had begun to wonder if that year's sailing season would see anyone bucking tradition and sailing the 400-odd nautical miles from Mangareva to Pitcairn and back-about 50 yachts made the trip that year heading in the other direction, generally en route from Rapanui (Easter Island) or the Galápagos to Tahiti, the Marquesas, the Cook Islands, or some combination thereof. Finally, eight months into life on Mangareva, my chance all but drifted into the village bay on high tide, under gentle coral-anxious power, in the form of the Brazil-machined solid steel hull of a 60 -foot yacht that was to collect a BBC television personality and fetch him to Pitcairn to conduct interviews for a book on far-flung British possessions, imperial jewels that shine the brighter for having been retained into the postcolonial era, but also 'the meanest inhabitable rocks in the seven seas', as he put it. I was tremendously gratified when the captain - the only person aboard and an internationally known sailor famous for solo cape-navigations, as it turned out-offered my wife and me the journey if I would crew and she cook a bit. So, with the lessons and admonitions of Charles Christian resounding in my head, before embarking I went around asking what folks might like to have taken to or collected from Pitcairn. 
At least a half-dozen different requests were made for watermelons which grow plentifully on Pitcairn, along with whatever other produce the horticulturally industrious Pitcairners happened to have a surplus of, which was thought to be whatever is in season since there were only so many Pitcairners then in residence ( 48 at the time) and the island's plateau is basically a single extended garden/orchard. Also, we were asked to post several letters - normally a letter posted to Pitcairn must travel to Tahiti, thence to New Zealand, and there suffer the vicissitudes of freight and fate, perhaps to depart on the multi-week journey to Pitcairn all but immediately, perhaps to rest in informational stasis for six months while the cargo cycle arrives at the next departure. In the most fruitful case, one of the island's three main store operators, Edmund, asked us to port two sacks of baguettes, about 100 in all, specially ordered and freshly baked. On Mangareva, the bakers generally know how many loaves will be wanted, purchased and consumed on the island on any given day to within a few loaves and are loath to overbake since flour is white gold. Edmund also asked us to carry two breadfruit saplings of a particular variety not under cultivation on Pitcairn that had been requested years earlier and were conveniently in season for transplantation. ${ }^{7}$ Now, obviously this struck us as deliciously ironic given the history of Pitcairn's settlement. ${ }^{8}$

$7 \quad$ Breadfruit is not readily transplanted out of a certain developmental season (Oliver 1988).

8 Pitcairn is famously the final stopping point of the mutinous dream-ship of libidinous liberty, HMAV Bounty. The Bounty mutineers had been fed up with Bligh's overbearing character and displacement of all human affection and existential concern onto the breadfruit saplings they had laboriously collected at Tahiti for transport to the West Indies (Dening 1992). Among other indignities early in the return voyage, the Bounty crew had to deal with an under-rationing of water as it was learned that breadfruit was intolerant of salt and must be regularly wetted down with fresh water to prevent early and rapid desiccation, defoliation and death. Of course, the first thing the mutineers did was throw the damned saplings overboard all the while jeering Bligh for his chlorophylliac inhumanity - in his defence, the man incontestably was greenthumbed and green-minded as he showed in his successful second breadfruit voyage (Dening 1992; Oliver 1988). In any event, the saplings had been requested by one of Pitcairn's residents, a sculptor, and would have been much appreciated had they not been intercepted at the landing by the High Commissioner himself, not usually in residence, who happened to be on the island, entomologist in tow, among other reasons for the very purpose of enforcing and promulgating stricter rules for the debarking of goods and the insects that stowaway in them-particularly the Cicadella 'pissing fly' now endemic in French Polynesia. On arriving, into the sea went our saplings too. 
Aside from such pleasantries, a more serious request arose, one which cast a personal light onto the notion of mana, which, as I noted above, had been bothering me for months and months due to the irregularity or near invisibility of its use.

Warren is a hard-working and not particularly affluent man who lives on the fringe of village life, about 1 kilometre in the $i$ mua direction. ${ }^{9}$ Warren and I saw one another and exchanged words daily as I passed his homestead and small pearl operation on my run, generally a shouted greeting and his comment on my form. Sometimes we would stop and chat at the far store. Once or twice we exchanged a few words of Pitcairnese (the particular speech community of that island developed out of English, Jack-Speak and 'Polynesian' in the late eighteenth, nineteenth and early twentieth centuries, e.g. you must have kill'd me for jump (you scared me)).

Warren is the son of Sterling Warren and Aunoa, a Mangarevan woman. Sterling and a group of other Pitcairners aboard the Pro Patria had been marooned on Temoe atoll in September 1933, and were rescued by Mangarevans after their presence on this atoll was discovered by a fishing expedition - coincidentally, James Norman Hall was also aboard the Pro Patria and recorded this event in his The Tale of a Shipwreck first published in the Atlantic Monthly in 1934. On a clear day, Mangareva can be seen from Temoe but rarely the reverse and then only from Taraetukura and Aororotini, the island's highest peaks. It was quite some time before a boat could be arranged to carry the Pitcairners back home - as I heard the story, no captain could be found at the time to undertake the voyage without a payment that was simply not available, and a number of unions were formed in the interim.

When a Captain Johnston of the commercial vessel Yankee finally agreed to transport the Pitcairners home, one of the couples that had formed in the meantime, Sterling and Aunoa, refused to be separated and Aunoa departed with the men for their home island. She was not the first Mangarevan woman so to do. They were married aboard the Yankee by Capt. Johnston, who noted in a letter of attestation to the

9 One of the non-cardinal directional orientations ordering normal transit on Mangareva, corresponding to travel away from the centre of town along the coast in a counter-clockwise direction. 
marriage, dated 1954 and stamped 'Certified True Copy' by the Island Secretary of Pitcairn in $1994,{ }^{10}$ that both parents had certified their willingness for Aunoa to be taken off the island despite her tender age (perhaps she was as young as 13).

Once on Pitcairn, the couple produced three children, two of whom returned with their mother to Mangareva, where they settled on family land and have remained to the present. Here the story intersects with the problematics of land tenure. Despite the passage of over one and a half centuries (longer on Tahiti) since colonial and commercial interests began to transform the rule of land in these islands from the traditional collective property rights rooted in tribe/clan-based membership, and complex land tenure (Newbury 1980; Finney 1965), only the last few years have seen any serious headway made in achieving transparency in, and the motivated dissolution of, collective proprietorship and usufruct rights (Bambridge and Neuffer 2002; Bambridge 2009). It is hard not to speculate that countervailing strategic interests resisted the reformation of land tenure with the tacit understanding that what happened in Hawai'i or New Zealand could happen in French Polynesia should a western fee simple/title system be implemented in these islands; and that it is the contemporary achievement of local quasisovereignty, termed autonomy, under a French constitution that has motivated various influential interests to expedite the process of legal reform after 150 years of delay (Bambridge 2009, 2012). In the years since the 1996 Statute of Autonomy, and intensively since the 2004 expansion of the autonomy framework, such reforms as have been implemented have led to a scramble for documents that could prove, or at least suggest to a judge, that you were one of a group of inheritors of rights over any particular piece of land as the demonstrably senior man or woman in a descent line (that is, the inheritor of a patronym which folks bear on Mangareva in quasi-titular manner, such as

10 The date is telling as it points to the time depths in which the family has been entangled in working to establish a legal identity and the evident decade (or longer) that Warren himself had been struggling to do so. I could add that I know Warren had approached others with similar requests both before and after the events described here. In 2006, notably, he was still in the process of advocating for his legal rights and of collecting evidentiary supports to legitimate his status and claims as evidenced in a remarkable blog posted to the SEA following news of the vessel SSV Robert C. Seamans (Sea Education Association 2006). 
'E Paeamara' and 'E Mamatui'), or, even better, the sole authentic proprietor of a particular land-among which documents a birth certificate was necessary. ${ }^{11}$

Which brings us to Warren's problem. He had no birth certificate on Mangareva demonstrating, legally, what everyone knew but some cousins were not willing or able to legitimately certify - that is, that as Aunoa's son he has legitimate rights (by birth, common agreement, customary law) to use of certain lands. Consequently, the previous few years had been increasingly anxious, as his perennial failure to prove descent to a series of French courts and judges - the 1954 attestation of his parents' marriage notwithstanding - had put his descendants' and his own titles, positions and economic futures on the line as cousins would step forward with their own rights to certain lands which will, in the future, become theirs exclusively should Warren not produce the proper evidence prior to the statutory limit set for this process. ${ }^{12}$

So, when on my daily run several nights before embarking, I stopped at Warren's to ask if I could take a letter or anything to Pitcairn for him, I was surprised to get an earful, a version of the situation I've just described along with a most personal request. In brief, he asked me if I would get a birth certificate made there for him, one that was specifically authorised by the state, a legitimate one that could serve as evidence for the various legal processes in which he was currently involved.

11 The problem of descent deserves its own extensive treatment. Folks sometimes today joke that there are only three families (Paeamara, Mamatui, Teapiki), though a number of other patronyms are still very much present (Teakarotu, Kopunui, Mamatamoe, among others). Members of the primary three gradually acquired large portions of the rule of the land since the collapse of the 'ati system.

12 The legislature has changed this ultimate date for the entire region several times, extending it on each occasion. I was initially told that 2005 was the limiting year, but understand that that changed while I was in the field, and the judge who visited Mangareva twice during my fieldwork to preside over various legal processes almost entirely devoted to land issues told me that he did not personally believe that some of the local land disputes would be resolved much sooner that 2020 or 2030 . We discussed Warren's case as an example. The judge's rationale for this claim was both occult, in that he would not share it publicly, and perverse in that he expected but would not publicise that many of the concerned, with evident rights and a certain degree of knowledge about the traditional constitution of those rights, would have to pass away in order to clear the ground for the re-assignment of specific rights to a smaller number of more easily identifiable individuals. His entropic presupposition, quite possibly erroneous, is that over time fewer individuals will be able to demonstrate that they have land rights 'before' the law based on customary knowledge. In fact, by 2009, many disputes had been settled far more concretely than anticipated. 
The conversation, impassioned on Warren's part and, on mine, nervous with the sense of responsibility and improbability that a Pitcairn authority would hand over a birth certificate, revolved around one term. Surprisingly, he used a singular conceptual frame to cover all of the different qualities of the object, cause, effect, event and the various tasks involved. Warren used mana and its causative form 'akamana to refer to what the Pitcairn authorities needed to do for this document - that is, to empower it, to legitimately authorise Warren's claims, in some sense his (legal) existence. At the same time, he referred to the document as mana and to mana as a character or quality of the incipient document. 'Na koe i 'akamana 'ia toku kaie, toku [birth] certificat' ('You will have made-mana (stamped, authorised) my paper, my birth certificate') he repeated while gesturing the action of stamping, with his hand serving as a virtual stamp.

A following conversation when I returned the next day to pick up a brief letter from Warren to be delivered to the Pitcairn authorities, stating his request in his own words, reconfirmed the pattern of his use of this concept - that is, the secular (or perhaps, considering the character of states, profane) or bio-political use of the term stuck out. Other senior speakers consulted in my language working group noted that Warren's usage was quite correct: 'akamana, to give authority to a document, was in fact exactly how this term should be used in everyday talk when appropriate.

What might be called the 'great works' uses of the term 'mana' described at the end of the last section accorded perfectly with what I expected to encounter as the actual use of this term in everyday speech, indeed virtually identical to the historically attested extensions of mana discussed at the outset in the section on bearing mana and its limits. I did not, however, expect such uses to be so rare or to be so parsimonious given the lushness of mana's semantic potential from either existing dictionaries or years of reading in the ethnography and history of Polynesian studies. Warren's conversation further challenged my sense of mana's semantic range or, rather, what that range reveals. Warren's speech and affirmations of it by others made me anxious about the seeming simplicity of previous usages. Contextualised by Warren's meaning, they seemed less indicative of a diffuse and ethereal supernatural force imbued in some things and persons than of the pragmatic powers of states and their agents manifest in the materiality of the everyday. 


\section{The mana of the state: Homo sacer in Polynesia?}

As amply demonstrated by Warren's usage above, mana is not always used in a manner to suggest the ineffable, metaphysical, flowing (or non-flowing) of some chthonic energy or supernatural quality (like 'luck') adherent to some persons and not others, or to certain things. Given these other uses of the term, the puzzle emerges of how this active 'mana' relates to mana in other contexts where it appears to be playing a descriptive role and what, if anything, this instance says about the scarcity of other uses or perhaps about the quotidianisation or anti-quotidianisation of mana across regional speech communities.

Bradd Shore (1989), in his major analysis of the term, certainly draws attention to the practical quality of mana as part of his analysis, but he also argues that mana's source can be shown to rest in the ineffable and the divine. Power is inherent in this world because it is transported here, authorised and legitimated from elsewhere or elsewhen. In addition, mana as a general principle of action in the world is relatable to fecundity. Shore notes that there is a ubiquitous linkage between the act, human or divine, and social reproduction as a matter of both physical and metaphysical import. Elsewhere in Polynesia, persons of mana literally inseminate the land in order to secure its future fertility, just as every application of potent force in human activity (re)produces some sort of social relation as did Tiki, on Mangareva, when he made the world meaningfully human through copulative acts (Buck 1938). 'In a number of Traditional societies, the high ariki endowed the land with his Mana, making it fruitful. This too, as we have seen, was a relationship of honor to the land' (Goldman 1970: 512). ${ }^{13}$ And, as a sort of tertium quid, Shore notes of the nature of mana that 'although western analysts have chosen to view mana as some kind of general and abstract force, Polynesians seem to emphasise a variety of particular powers, or at the very least specific manifestations of a general concept' (Shore 1989: 138). Is mana

13 'The specific quality of Fijian chiefly power (kaukawa [sic] or mana) is masculine potency, a virility that has more than one representation in common custom. It appears directly, for example, in the paramount's privileged access to nubile women of his domain; symbolically, in the correspondence between the rites of chiefly investiture and the initiation of young men to sexual and warrior status by circumcision' (Sahlins 1976: 26). 
a field of force or a flowing current of power, or a simple substance which, like dark matter and dark energy, is nowhere visible but latent in the cosmic order of things? Or is mana something else, a word in use that indexes or summons into contextual relevance a local, culturally nuanced bundle of understandings about the ordering of things and the forces (more or less authorised) behind or in front of that ordering?

The tension between the ineffable spiritual and the practical and administrative is highly visible in Warren's request for a state document, a certificate legitimating his birth and being, one that must literally be fabricated and authorised, by stamp and seal, as valid in the context of highly sensitive micro-political social processes, as when at law. Equally suggestive is the presupposed lack of absence or insufficiency of mana in Warren's existing documentation. This state of affairs, at once personal and impersonal, local and extralocal, legal and extralegal, strikingly resembles the condition of homo sacer identified by Giorgio Agamben (1998) as an extraordinary tool for making visible regimes of sovereign state power. While I do not propose a close exegesis of Agamben's Homo Sacer cycle, I do want to pursue several points in relation to it that clarify several of the tensions in understanding contemporary mana, its relations to the past, and its transformations in French Polynesia.

In Roman law, homo sacer is a person whose bios (political life) has been legally stripped away and who is thus reduced to zoe (bare life, animal life). Such beings are subject to the capricious whims of those around them who may kill them (or impede lesser rights also derived from bios) as they will. However, with dark irony, homo sacer may not be sacrificed. Presumably a human sacrifice requires recognition of bios, the value of a fundamentally social and political being equivalent to the significance of the sacrifice, and the homo sacer has been reduced to bare life or zoe. Agamben himself locates mana within the analytical framework of the fraught condition of homo sacer. The central passage is worth quoting in its entirety.

An enigmatic archaic Roman legal figure that seems to embody contradictory traits and therefore had to be explained thus begins to resonate with the religious category of the sacred when this category irrevocably loses its significance and comes to assume contradictory meanings. Once placed in relation with the ethnographic concept of taboo, this ambivalence is then used - with perfect circularity to explain the figure of homo sacer. There is a moment in the life of 
concepts when they lose their immediate intelligibility and can then, like all empty terms, be overburdened with contradictory meanings. For the religious phenomenon, this moment coincides with the point at which anthropology - for which the ambivalent terms mana, taboo, and sacer are absolutely central - was born at the end of the last century. Levi-Strauss has shown how the term mana functions as an excessive signifier with no meaning other than that of marking an excess of the signifying function over all signifieds. Somewhat analogous remarks could be made with reference to the use and function of the concepts of the sacred and the taboo in the discourse of the social sciences between 1890 and 1940. An assumed ambivalence of the generic religious category of the sacred cannot explain the juridicopolitical phenomenon to which the most ancient meaning of the term sacer refers. On the contrary, only an attentive and unprejudiced delimitation of the respective fields of the political and the religious will make it possible to understand the history of their intersection and complex relations. (Agamben 1998: 51, emphasis added)

What then does an attentive and unprejudiced inquisition of mana at the intersections of the political and religious framed anew through the lens of homo sacer achieve (with delicious parallel to Mauss' use of Roman law in 'the discourse of the social sciences between 1890 and 1940')? Perhaps it raises the question of the source of the power to reduce a person (or persons) to bare life, to remove their bios or political being and subject them to existential contingency without the protections of social order. Agamben observes that this power, which can be reduced to the right to kill, is the essence of sovereignty. Which is to say, it is a power whose source cannot be found in nature, identified as imperium in Roman law, and which was (and continues to be) wielded by state agents, persons personifying political regimes such as magistrates who through auctoritas enacted the rule of law ultimately grounded in imperium. Homo sacer, this curious or enigmatic condition, is specifically interesting because its enactment makes visible the fundamental tension between the absolute limits of power, imperium (sovereignty, authority over the death of bios-constituted beings), the legitimated powers of state agents wielding auctoritas, and the everyday powers of lesser agents or citizens enacting their own political or social powers as potestas.

My point in drawing attention to Agamben is to emphasise that the history of mana's uptake in anthropology can come into focus as a point of disciplinary and cross-disciplinary fetishisation of the numinous 
and ineffable in the perception, conception and experience of the exercise of power over human entities (those bearing bios) and culturespecific explanations thereof. Coming out of my experience of seeking to honour Warren's request in friendship, what strikes me most about mana's anthropological uptake is how the concept-in-use appears to be far more readily translatable under most or possibly all of its actual contexts into more familiar cultural terms than suggested by all of the ink spilled over its presupposed 'numinous' content. The practical contexts of mana's rare but forceful appearance in everyday speech on Mangareva has left me skeptical of anthropology's lingering willfulness to ascribe to Polynesian (or Oceanic) mana a greater degree of mysticism, amazement, or miraculousness than ascribed to western conceptions of legal authority and the powers of states through their agents and objects, for instance in legal documents processed through more or less bureaucratised institutions. Recalling the derived forms of mana pointing to collective powers, of the authority of the social or of the 'state' broadly defined as those regimes of power (authority) bearing effects on any given community, mana thus might be seen to be a culturally specific working out of issues of authority, power and social force that have been worked out in other parts of the world in terms of imperium and auctoritas (the authority of sovereigns, states, political regimes, collectives, or their agents).

To the best of my knowledge, there is only one other instance of the use of mana in the entire corpus of traditional Mangarevan textsone highly suggestive of this reading. Mana appears one time in the 58 pages of the Code Mangarévien, the books of laws enacted and published in the dusk of the Mangarevan Kingdom in 1881, a process entangled in the historical incorporation of the kingdom into a French territory. Including the Constitution, civil code and code of justice of the land, in both a French (first) and Mangarevan (second) version, this document invokes mana only once, in the fifth line of the Mangarevan version, in the first article of the constitutional accord. 
TE UGA NEI: Art. 1. Ka akamana tapu kehekehe hia, ki roto i a mau Kaiga Mangareva nei, a mau Ture Mangareva i akatu hia mei te makararaga i rotopu i te mau Tagata ao o te kaiga nei, me to Komagata Kaireo o te Repupirika Harani. (Richard 2001: 127) ${ }^{14}$

BE IT KNOWN: Art. 1. By utter sacredness [tapu kehekehe] 'akamanaed, inside all Mangarevan lands, the Mangarevan Laws [are] hereby made-to-stand in the deep (absolute depths, rotopu) of the minds (thoughts) of the People of these lands, and the Commandant [Komagata] Commissioner (kairea: 'a deputy; an envoy; a delegate. One who is embued with the authority of another', in Tregear [1899]) of the French Republic [my translation].

In this context, as in Warren's uses of the term described above, the potency and authority of the state is the significant (non-ambiguous) and semantic heart of the term, one reinforced-just in case any of the Tagata ao o tera kaiga ra (local citizens) somehow missed the imperium involved - with an explicit assertion of the tapu kehekehe (utter sacrality; hence force) of these akamana-ed words (see also Silva, this volume).

This re-reading stands in contrast to Sahlins (1985) and a century of other scholars who I suggest could be productively re-read in conversation with Agamben's attempt to produce an 'attentive and unprejudiced delimitation of the respective fields of the political and the religious [that] will make it possible to understand the history of their intersection and complex relations' (Agamben 1998: 51), one that does not over-emphasise the supernatural and extraordinary majesty of individuals instead of their magisterial authority derived from imperium or auctoritas (whether legendary heroes, or chiefs, or British naval officers who overstepped their mana to disastrous results, or Colonial Commissioners, or everyday bureaucrats). In this reading, other reflexes of mana are semantically rooted in the same field of significance, one in which mana is evident in every marvellous or amazing or unlikely human act not because of the supernatural, beyond-the-common, or otherworldly dimension of spectral power, but because it takes a state, an authorised regime, to move a boulder uphill, to erect an edifice, to achieve a victory, or to compel others to

14 The passage in the French version: 'ORDONNE: Art. 1. Est promulgué dans l'archipel des Gambier (Mangareva) le Code mangarévien établi d'un commun accord entre les représentants du pays et le Commandant Commissaire de la reunion de la République Française' (Richard 2001: 96). 
follow an everyday command from a singular individual. E mea mana (all these things), including the simple act of a mayor in a British colony in the post office building, making a photocopy of a birth certificate, signing a short letter attesting its validity, enclosing it in an envelope, signing the flap, and sending it across the sea. This is mana.

\section{Conclusion: Quotidianisation and anti-quotidianisation}

In conclusion, my premise is that on Mangareva most speakers are like Warren in their regularities of usage regarding this term. Friends and colleagues on Mangareva rarely speak about mana-things and manaworks (in French or Tahitian or Mangarevan) in contexts that suggest a heightened quality attached to certain things and superlative persons. However, as a matter of everyday speech acts and semantics, on no occasion did any speak as if they perceived spectral and flowing supernatural qualities inherent in persons or acts. All of which leaves me exceedingly sceptical about whether Mangarevan persons today conceive of mana as a sort of universal field of supernatural energy, the force par excellence, that is by the ontologically otherworldly status of some persons and certain things beyond normal efficaciousness. Warren's usage and others' confirmation of it suggested, however, that certain acts of mana did in fact produce effects and changes in the world, and did in fact have a special quality. As a Mangarevan colleague put it in a phrase perhaps worth repeating, 'mana is a tapu word' and there is a significant and enduring culture of anti-quotidianisation of invocation of the term in everyday speech. It seems to me that mana on Mangareva prototypically summons into real-time discourse certain local and culturally nuanced understandings of the practical and pragmatic powers of imperium and auctoritas, thus making visible the clash between potestas and these higher order regimes of power. Such contexts are, of course, utterly weighty, and perhaps point to the 'setting aside' (tapu) of the use of this term in everyday life. English too, and many other languages, have set aside terms reserved for the lightning-wielding (auctoritas-bearing) agents of the state's imperium, for example, 'Your Honour' or 'Your Majesty'. Mana thus resonates with its ethnological use as a conceptual origo which calibrates and allows one to make sense of 'specific notions about kinship, relationships between human beings and ancestral gods, and a host 
of related beliefs' (Kirch and Green 2001: 59) in the material outcomes of collective acts, including those of individuals who, in some sense, represent the state or, in elder days, their prevailing regimes of power and authority.

As discussed at the outset, my own first-order experience of the term mana surprised me by the scarcity of its use. Recall, Warren's possessions, rights, and those of his descendants had been put at risk because of a problematic lack of paper documentation of his existence as a byproduct of his birth on Pitcairn. In brief, he asked me if I would get a birth certificate made there for him, one that was specifically authorised by the state, a legitimate one that could serve as evidence for the various legal processes in which he was currently involved. Surprisingly, Warren used mana and its causative form 'akamana again and again to refer to what Pitcairn authorities needed to do for this document - to empower it, to authorise his claims and, from the point of view of the French state, his legal existence. At the same time, he referred to the document's legitimacy as a question of mana (previous letters of attestation secured through correspondence with the Pitcairn administration and presented to the land judge on Mangareva were said to be without legitimacy) and to mana as the 'stamp' of authority by the Pitcairn administration and by the authority of the French judge who presided over the long-running land crisis in this part of Polynesia (complete with gestural mime of the 'stamping process' and indexical fingering of the stamp itself).

I suggest that Warren's mana and that of his Mangarevan community is clarifying. This discussion of mana casts light on the local value of certain heightened terms in everyday talk over time. In the Society Islands, where the power of the state to regulate collectives and to arbitrate bios has been under decades of active contestation and legal (re)negotiation, is it any surprise that mana is quotidianising? In the Gambier Islands, as elsewhere in French Polynesia's outer islands, where the experience of and response to the fact of enduring French colonialism has included a greater degree of ambivalence about a regional future independent from or autonomous within France, and despite massive language shift and loss, the use of mana in everyday speech appears to be resisting change - at least in the sense of increased invocation. Perhaps this too is unsurprising inasmuch as the everyday economies of linguistic power can track and index broader political tensions and struggles. 
The sense of mana as miraculous, flowing power is an excellent example of what might be called a metaphorical figuration of a more straightforward conception of a majestically complex thing (the imperium of past and present states and their agents). Did past speakers conceive of mana as miraculous and supernatural or as worldly and very much the possession of certain men and women within particular regimes of authority? Men, women and collectives who possessed mana possessed auctoritas or represented imperium. Extraordinary things require extraordinary labours and the organisations and administrations of authorities to achieve them. Conspicuously, this does not make them less amazing or marvellous, or even less miraculous. With an eye towards the chronotope of past powers and marvels and a seeming diminution implicit in mana's regular expression about things-of-yesterday (Tomlinson 2006) on Mangareva, from something like Warren's point of view, Mangarevans would not be wrong to claim that their ancestors had more mana than they do today. As practical, pragmatic power, as literally the 'rule of the land', mana was indeed a possession of the ancient tupuna as a government administered by both chiefly and priestly ancestors with imperium and auctoritas. In a difficult position on a small island on the fringe of a global colonial empire, it is clear that states do not always or easily lend citizens their lightning. Today, it can be tragically difficult to 'akamana local political initiatives and practices. But, with reference to the quotidianisation of mana on Tahiti, and the fact that some contemporary mana may be caught up in global and regional capital logics notwithstanding, perhaps there is reason to be hopeful for a relocalisation of imperium and auctoritas.

Throughout, I have noted that mana is used differently in Tahiti and Mangareva. Indeed, it is hardly used in Mangarevan conversations or contexts relative to those of Tahiti, where it was once invoked far less frequently than one would think given all the anthropological ink and its present visibility on the communicative landscape, or given its attested semantic lushness and imputed verdancy. I suggest the change in the semantic extension of the term over time on Tahiti represents a process of quotidianisation whose activity tracks a desire for the democratisation of sovereignty in an enduringly colonial situation. This is not the case on Mangareva where many continue to avoid the use of this term in everyday life except in highly rarefied circumstances such as when discussing the imperium of state powers 
or the auctoritas of government officials, a process I describe as antiquotidianisation. Certainly it is easy to wonder how mana's trajectories of use are changing elsewhere in the region - what roles mana might be playing in conceiving and experiencing and responding to contemporary states and other regimes of power such as transnational commerce and potent local currents of social and political renewal. An interesting result of mana's movements in French Polynesia is that, contra Weber, some aspects of social and cultural life have remained or become progressively more enchanted in an age of westernisation, bureaucratisation and modernisation. Moreover, this process may indicate a resurgence of 'new' mana even as it harks back, sometimes wistfully, to the potency of the old.

\section{Acknowledgements}

I offer a heartfelt thanks to Matt Tomlinson and Ty Tengan for organising the New Mana initiative and for their generous support and encouragement. A hearty maroi is also due to Erwin Warren and many others in the punui of Rikitea for sharing their mana and for gifts of words about the present and the past, and particularly to Nikola Mamatamoe, Daniel Teakarotu and Bruno Schmidt. Many thanks too to Ena Manuireva for sharing his mana o te reo Mangareva.

\section{References}

\section{Archival Repository}

British Museum Archives:

MS PAC Mangareva 3.3. [MPM 3.3.], n.d.

MS PAC Mangareva 3.4. [MPM 3.4.], n.d.

\section{Books, journal articles and chapters}

Agamben, Giorgio. 1998. Homo Sacer: Sovereign Power and Bare Life, trans. Daniel Heller-Roazen. Stanford, CA: Stanford University Press. 
Appadurai, Arjun. 1996. Modernity at Large: Cultural Dimensions of Globalization. Minneapolis: University of Minnesota Press.

Bambridge, Tamatoa. 2009. La terre dans l'archipel des Australes. Étude du pluralisme juridique et culturel en matière foncière. Papeete: Institut de Recherche pour le Développement (IRD) et Aux Vents des Îles.

—. 2012. Le foncier terrestre et marin en Polynésie française: L'étude de cas de Teahupoo. Land Tenure Journal 2: 119-43.

Bambridge, Tamatoa and Philippe Neuffer. 2002. Pluralisme culturel et juridique: le foncier en Polynésie française. In La France et les Outre-Mers, ed. Tamatoa Bambridge, JeanPierre Doumenge, O. Bruno, J. Simonin, D. Wolton, pp. 307-15. L'enjeu multiculturel, CNRS Éditions, Hermès, no. 32-33.

Baré, Jean-François. 1987. Tahiti, Les Temps et Les Pouvoirs: Pour une anthropologie historique du Tahiti post-européen. Paris: Éditions de l'Orstom.

Blevins, Juliette. 2008. Some comparative notes on proto-Oceanic *mana: Inside and outside the Austronesian family. Oceanic Linguistics 47(2): 253-74.

Blust, Robert. 2007. Proto-Oceanic *mana revisited. Oceanic Linguistics 46(2): 404-23.

Buck, Peter H. [Te Rangi Hiroa]. 1938. Ethnology of Mangareva. Honolulu: Bernice P. Bishop Museum Press.

Buse, Jasper with Raututi Taringa. 1985. Cook Islands Maori Dictionary, ed. Bruce Biggs and Rangi Moeka'a. Canberra: ANU Printing Service.

Codrington, R.H. 1891. The Melanesians: Studies in their Anthropology and Folk-lore. Oxford: Clarendon Press.

Davies, John. 1991 [1851]. Tahitian and English Dictionary with Introductory Remarks on the Polynesian Language and a Short Grammar of the Tahitian Dialect: With an Appendix. Tahiti: Editions Haere Po. 
Dening, Greg. 1980. Islands and Beaches: Discourse on a Silent Land: Marquesas 1774-1880. Honolulu: University of Hawai'i Press.

- 1992. Mr. Bligh's Bad Language: Passion, Power and Theatre on the Bounty. New York: Cambridge University Press.

Dordillon, Mgr. I.R. 1999 [1904]. Grammaire et Dictionnaire de la Langue des Îles Marquises. Tahiti: Société des Etudes Océaniennes.

Finney, Ben, 1965. Polynesian Peasants and Proletarians: Socio-economic Change among the Tahitians of French Polynesia. Wellington: Polynesian Society.

Firth, Raymond. 1940. The analysis of mana: An empirical approach. Journal of the Polynesian Society 49: 483-510.

Goldman, Irving. 1970. Ancient Polynesian Society. Chicago: University of Chicago Press.

Hall, James Norman. 1934. The Tale of a Shipwreck. Boston: Houghton Mifflin Co.

Holbraad, Martin. 2009. The power of powder: Life-force and motility in Cuban adivination. Bedeutung 1(3): 42-56.

Hubert, Henri and Marcel Mauss. 1902-1903. Esquisse d'une théorie générale de la magie. L'Année Sociologique 7: 1-146.

[Janeau, Vincent Ferrier]. 1908. Grammaire et dictionaire Mangaréviens, par les Missionaires Catholiques de cet Archipel. Members de la Congrégation des Sacres-Cours de Picpus, Braine-le-Comte.

Keesing, Roger M. 1984. Rethinking 'mana'. Journal of Anthropological Research 40(1): 137-56.

Kirch, Patrick Vinton and Roger C. Green. 2001. Hawaiki, Ancestral Polynesia: An Essay in Historical Anthropology. Cambridge: Cambridge University Press.

Lévi-Strauss, Claude. 1987. Introduction to the work of Marcel Mauss. London: Routledge.

Manapearl. 2015. Be a MANA-BOY. Online: www.maison-perle-tahiti. com/manapearl-tahiti/ (accessed 16 October 2015). 
Mana Ori Tahiti. 2015. Online: tahitienfrance.free.fr/associations/ assosculturelles/mana_ori_tahiti.htm (accessed 16 October 2015).

Mana Rock Café. 2015. Mana Rock Café. Online: facebook.com/rock. manal (accessed 16 October 2015).

Newbury, Colin. 1980. Tahiti Nui: Change and Survival in French Polynesia, 1767-1945. Honolulu: University of Hawai'i Press.

Oliver, Douglas. 1974. Ancient Tahitian Society. Honolulu: University of Hawai'i Press.

—_. 1988 [with William Bligh]. Return to Tahiti: Bligh's Second Breadfruit Voyage. Honolulu: University of Hawai'i Press.

- 2002. On Becoming Old in Early Tahiti and in Early Hawai'i. Tahiti: Societe des Etudes Oceaniennes/Haere Po.

Putigny, Robert. 1993 [1975]. Le mana: ou, Le pouvoir surnaturel en Polynésie. Paris: Editions R. Laffont.

Richard, Vahi Sylvia (ed.). 2001. Code des lois /Cahiers du Patrimoine: Histoire]. Tahiti: Ministère de la Culture ed de l'Enseignement supérieur.

Sahlins, Marshall. 1976. Culture and Practical Reason. Chicago: University of Chicago Press.

— 1985. Islands of History. Chicago: University of Chicago Press.

Sea Education Association. 2006. Following Sea. Online: www.sea. edu/followingsea/3-06/f2_2_3-06.aspx (accessed 2 October 2015).

Shore, Bradd. 1989. Mana and tapu. In Developments in Polynesian Ethnology, ed. Alan Howard and Robert Borofsky, pp. 137-73. Honolulu: University of Hawai'i Press.

Tomlinson, Matt. 2006. Retheorizing mana: Bible translation and discourse of loss in Fiji. Oceania 76(2): 173-85.

Tregear, Edward. 1899. A Dictionary of Mangareva (or Gambier Islands). Wellington: John Mackay.

Valeri, Valerio. 1985. Kingship and Sacrifice: Ritual and Society in Ancient Hawaii. Chicago: University of Chicago Press. 
This text is taken from New Mana: Transformations of a Classic Concept in Pacific Languages and Cultures, edited by Matt Tomlinson and Ty P. Kāwika Tengan, published 2016 by ANU Press, The Australian National University, Canberra, Australia. 